\title{
Correction to: Evaluating caregivers' service quality perceptions: impact-range performance and asymmetry analyses
}

Wen-Fu Wang ${ }^{1,2+}$, Chun-Min Chen ${ }^{3+}$, Kai-Ming Jhang ${ }^{1}$ and Yung-Yu Su ${ }^{4 *}$

\section{Correction to: BMC Health Serv Res 22, 183 (2022) \\ https://doi.org/10.1186/s12913-022-07594-2 \\ Following publication of the original article [1], the authors identified an error in Fig. 2. The updated Fig. 2 provides a level illustration of Fig. 2. Several corrections have been made, including text above figure (Low impact, Medium impact, and High impact), and text in the center (Delighters, Satisfiers, Hybrids, Dissatisfiers, and Frustra- tors). The correct figure is given below.}

The original article has been corrected.

\section{Author details}

'Department of Neurology, Changhua Christian Hospital, Changhua, Taiwan. ${ }^{2}$ Department of Recreation and Holistic Wellness, Ming Dao University, Changhua, Taiwan. ${ }^{3}$ Big Data Center, Changhua Christian Hospital, Changhua, Taiwan. ${ }^{4}$ Department of Long-Term Care, National Quemoy University, No. 1, University

Rd., Jinning Township, Kinmen County 892, Kinmen, Taiwan, Republic of China.

Published online: 02 March 2022

\footnotetext{
Reference

1. Wang, et al. Evaluating caregivers'service quality perceptions: impactrange performance and asymmetry analyses. BMC Health Serv Res. 2022;22:183. https://doi.org/10.1186/s12913-022-07594-2.
}

The original article can be found online at https://doi.org/10.1186/s12913022-07594-2.

*Correspondence: yungyu@nqu.edu.tw; yys949@gmail.com

'Wen-Fu Wang and Chun-Min Chen contributed equally to this work.

${ }^{4}$ Department of Long-Term Care, National Quemoy University, No. 1. University Rd., Jinning Township, Kinmen County 892, Kinmen, Taiwan, Republic of China

Full list of author information is available at the end of the article

(C) The Author(s) 2022. Open Access This article is licensed under a Creative Commons Attribution 4.0 International License, which permits use, sharing, adaptation, distribution and reproduction in any medium or format, as long as you give appropriate credit to the original author(s) and the source, provide a link to the Creative Commons licence, and indicate if changes were made. The images or other third party material in this article are included in the article's Creative Commons licence, unless indicated otherwise in a credit line to the material. If material is not included in the article's Creative Commons licence and your intended use is not permitted by statutory regulation or exceeds the permitted use, you will need to obtain permission directly from the copyright holder. To view a copy of this licence, visit http://creativecommons.org/licenses/by/4.0/. The Creative Commons Public Domain Dedication waiver (http://creativeco mmons.org/publicdomain/zero/1.0/) applies to the data made available in this article, unless otherwise stated in a credit line to the data. 


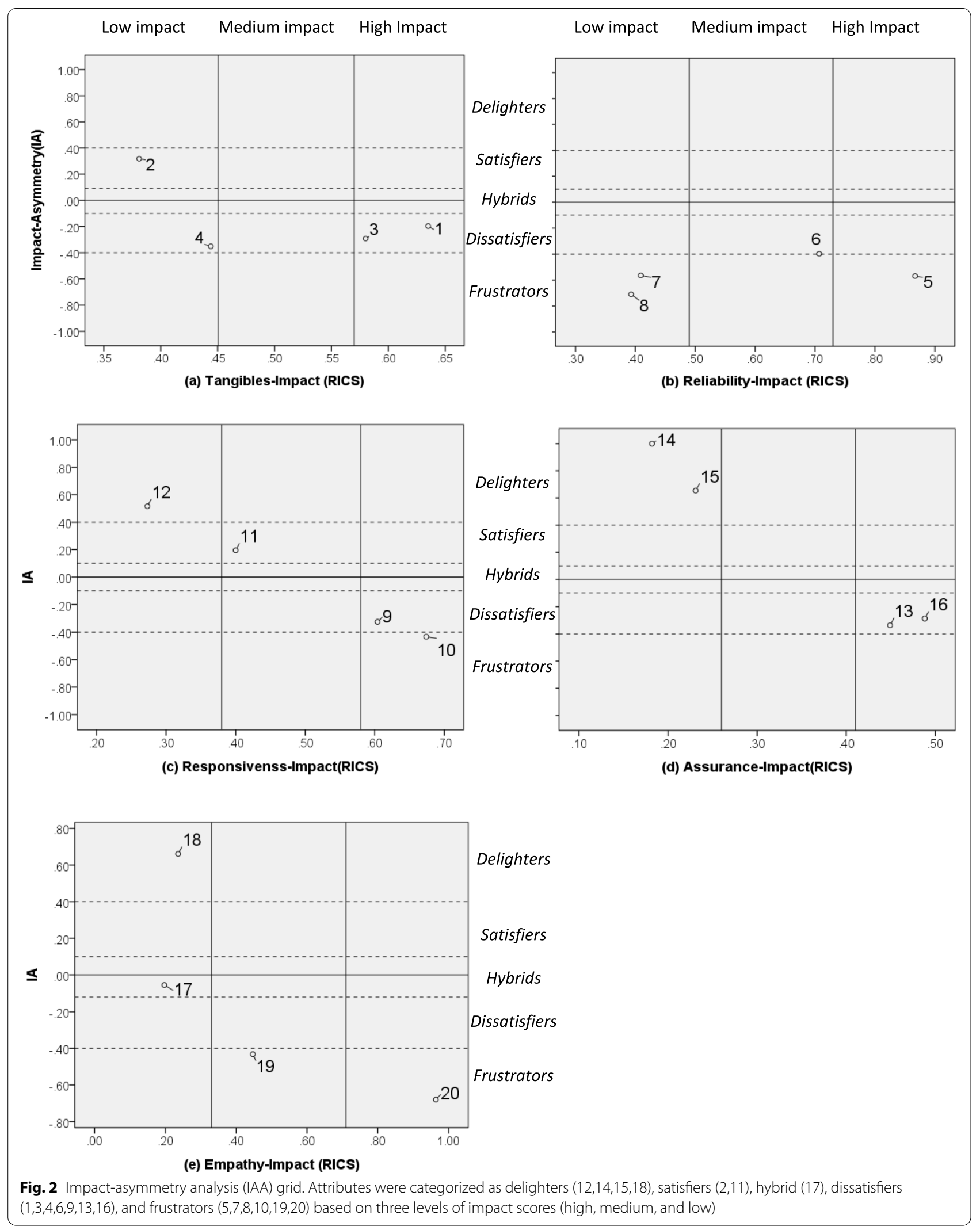

